University of Nebraska - Lincoln

DigitalCommons@University of Nebraska - Lincoln

1990

\title{
Alkali-Labile Cell-Wall Phenolics and Forage Quality in Switchgrasses Selected for Differing Digestibility
}

B. C. Gabrielsen

Kenneth P. Vogel

University of Nebraska-Lincoln, kvogel1@unl.edu

J. K. Ward

University of Nebraska-Lincoln

Follow this and additional works at: https://digitalcommons.unl.edu/usdaarsfacpub

Gabrielsen, B. C.; Vogel, Kenneth P.; and Ward, J. K., "Alkali-Labile Cell-Wall Phenolics and Forage Quality in Switchgrasses Selected for Differing Digestibility" (1990). Publications from USDA-ARS / UNL Faculty. 1879.

https://digitalcommons.unl.edu/usdaarsfacpub/1879

This Article is brought to you for free and open access by the U.S. Department of Agriculture: Agricultural Research Service, Lincoln, Nebraska at DigitalCommons@University of Nebraska - Lincoln. It has been accepted for inclusion in Publications from USDA-ARS / UNL Faculty by an authorized administrator of DigitalCommons@University of Nebraska - Lincoln. 


\title{
CROP QUALITY \& UTILIZATION
}

\section{Alkali-Labile Cell-Wall Phenolics and Forage Quality in Switchgrasses Selected for Differing Digestibility}

\author{
B. C. Gabrielsen, K. P. Vogel,* B. E. Anderson, and J. K. Ward
}

\begin{abstract}
Alkali-labile cell-wall phenolics have been implicated in previous research as factors that affect forage digestibility by ruminants. Alkali-labile cell-wall phenolics, in vitro dry matter digestibility (IVDMD), neutral-detergent fiber (NDF), acid-detergent fiber (ADF), lignin (permanganate-oxidation), and crude protein (CP) were determined in three switchgrass (Panicum virgatum L.) strains differing genetically for IVDMD to determine relationships between these quality parameters and IVDMD during the grazing season. Grazed (upper $1 / 3$ of grazed plants) and ungrazed (whole plants in caged exclosures) forage was collected weekly from replicated 0.4ha pastures of 'Trailblazer' (high IVDMD), 'Pathfinder', and a lowIVDMD strain during three grazing seasons from 1983 to 1985 . The principal alkali-labile phenolics ( $\mathrm{g} \mathrm{kg}^{-1} \mathrm{NDF}$ ) detected were $p$-coumaric acid (PCA) and ferulic acid (FA). Increased PCA concentration due to increased maturity averaged $>\mathbf{7 0} \%$ during each grazing season and corresponded with increased NDF, ADF, and lignin and decreased IVDMD, CP, and FA/PCA ratio. Ferulic acid concentration either declined slightly or remained unchanged. Averaged across 3 yr, Trailblazer had higher $(P<0.06)$ IVDMD, lower $(P$ $<0.09)$ PCA and higher $(P<0.10)$ FA/PCA ratio than a divergently selected low-IVDMD strain. Differences between strains in detergent-fiber constituents, $F A$, and $C P$ were either not apparent or inconsistent with strain differences in IVDMD. Results were consistent with both grazed and ungrazed switchgrass and indicate that alkali-labile cell-wall phenolic composition in switchgrass is heritable and genetically correlated to IVDMD.
\end{abstract}

B.C. Gabrielsen (formerly USDA-ARS), J.M. Lord, Inc., $267 \mathrm{~N}$. Fulton, Fresno, CA 93701; K.P. Vogel, USDA-ARS and Dep. of Agronomy, B.E. Anderson, Dep. of Agronomy, and J.K. Ward, Dep. of Animal Science, Univ. of Nebraska, Lincoln, NE 68583. Paper no. 8634 of the Journal Series of the Nebraska Agricultural Research Division in cooperation with the USDA-ARS. Received 15 June 1989. * Corresponding author.

Published in Crop Sci. 30:1313-1320 (1990).
工 IGNIFICATION is associated with reduced forage digestibility (Moore and Mott, 1973; Cowling 1975; Jung and Vogel, 1986) and poor animal performance (Duble et al., 1971), although the precise mechanism by which this control is exerted is unclear. Some studies (Van Soest, 1973; Cowling, 1975) suggest that lignin functions to physically prevent accessibility of digestive enzymes. Other evidence (Hartley, 1972; Morrison, 1974; Gaillard and Richards, 1975) indicates that lignin is chemically linked to cell-wall carbohydrates, which also limit digestion.

In grasses, lignin may be partitioned into core and noncore fractions (Hartley, 1972; Gordon, 1975). Core lignin arises from three phenylpropanoid monomers ( $p$-coumaryl, coniferyl, and sinapyl alcohols), which are interconnected in varying proportions and random sequences, primarily through $\mathrm{C}-\mathrm{C}$ bonds and ether linkages (Harkin, 1973). Noncore lignin consists mainly of ester-linked PCA and FA (Hartley, 1972).

Information pertaining to changes in noncore lignin components during forage maturation and their relationship to cell-wall fiber constituents and forage digestibility is limited. Most studies have examined legumes and cool-season grasses (Hartley and Jones, 1977; Burritt et al., 1984; Scalbert et al., 1985); however comparable research involving temperate warmseason forage grasses, such as switchgrass, has not been reported.

Vogel et al. (1981) described the progress achieved in improving switchgrass IVDMD following one cycle of divergent selection. Although the high- and lowIVDMD strains resulting from this work were similar in maturity and forage yield, differences in IVDMD were significant. Subsequent research (Vogel et al., 
1984) indicated that hay quality of the high- and lowIVDMD strains and Pathfinder switchgrass was comparable when using the detergent system of analysis (Goering and Van Soest, 1970). Similar results with these same strains were obtained by Anderson et al. (1988) for herbage collected during grazing trials with yearling cattle (Bos taurus). However, superior average daily gains were obtained for animals grazing the high-IVDMD strain (Trailblazer). Ward et al. (1989) showed that there was not any differential selectivity by esophageal-fistulated steers grazing these grasses. These studies indicate that differences among switchgrass strains for IVDMD and animal performance are not adequately explained by the detergent-system forage-quality parameters. It is possible that selection for increased IVDMD in switchgrass breeding programs may alter alkali-labile cell-wall phenolic composition and thereby contribute to improved fiber digestion in ruminants.

The objectives of this study were to (i) determine the effect of maturity on alkali-labile cell-wall phenolics (i.e., noncore lignin), forage fiber constituents, and crude protein in grazed and ungrazed switchgrass and (ii) determine if the genetic differences among the switchgrass strains described previously for IVDMD are associated with differences in alkali-labile lignin phenolics.

\section{MATERIALS AND METHODS}

The study was conducted during three grazing seasons from 1983 through 1985 at the University of Nebraska Agricultural Research and Development Center near Mead, NE. In 1981, three switchgrass strains, Trailblazer, Pathfinder and a low-IVDMD type (Vogel et al., 1981), were established in 120.4-ha pastures in a randomized completeblock arrangement with four replicates per strain. Soil type, planting procedures, stocking rates, and grazing periods were as previously described (Anderson et al., 1988). In 1984, a forage selectivity trial was conducted that utilized beef yearlings and mature, crossbred, esophageal-fistulated steers (Ward et al., 1989). In that study, grazing was initiated on 1 June and terminated 6 August; however, animal performance data were not compiled.

Throughout these grazing trials (Anderson et al., 1988; Ward et al., 1989), the animals selectively grazed the top one-third of the canopy. Therefore, forage samples designated as grazed were randomly clipped at $\sim 1$-wk intervals from the upper one-third of the grazed plants within each pasture. Sampling periods were initiated and terminated each year to coincide with the first and last day of grazing, respectively. In 1984 and 1985, ungrazed forage samples also were collected using caged exclosures following the same clipping schedule as above. Four exclosures, measuring 1.2 by 1.5 by $1.5 \mathrm{~m}$, were randomly placed within each pasture. On each sampling date, a forage subsample within the exclosures was clipped to a $7.5-\mathrm{cm}$ stubble height and composited. Clipped plants within an exclosure were not resampled. The cages were relocated within the pastures each year. Forage samples were collected from four replicates during 1983; however, in 1984 and 1985, only two pasture replicates of each forage strain were used, due to a limited number of available exclosures. Samples were dried in paper bags at $55^{\circ} \mathrm{C}$ in a forced-draft oven, ground to pass a $1-\mathrm{mm}$ screen in a Wiley ${ }^{l}$ mill, and stored in plastic vials at room temperature until analyzed.

Estimates of forage digestibility (IVDMD) used the two-

\footnotetext{
${ }^{1}$ Names of products are included for the benefit of the reader and do not imply endorsement by the USDA or the University of Nebraska.
}

stage method of Tilley and Terry (1963) with minor modifications $\left(\mathrm{HgCl}_{2}\right.$ and $\mathrm{Na}_{2} \mathrm{Co}_{3}$ were not added after the first step). The rumen fluid was a mixture taken from two fistulated steers maintained on separate diets of alfalfa ( $\mathrm{Med}$ icago sativa L.)-smooth bromegrass (Bromus inermis Leyss.) hay or ground corn (Zea mays L.) cobs. Crude protein $(\mathrm{N} \times 6.25)$ was determined following the Kjeldahl procedure (AOAC, 1975). Neutral-detergent fiber, ADF, and lignin (permanganate-oxidation) concentration were sequentially determined as described by Van Soest and Robertson (1980)

Alkali-labile phenolics were extracted from air-dried NDF residues $(0.5 \mathrm{~g})$ in $1 M \mathrm{NaOH}(20 \mathrm{~mL})$ (Hartley, 1972). The residue was agitated in a water bath at $20^{\circ} \mathrm{C}$ for $\sim 20 \mathrm{~h}$, filtered through a coarse-porosity sintered glass crucible, and washed thoroughly with distilled water. The filtrate was immediately acidified to $\mathrm{pH} 2.5$ using $6 \mathrm{M} \mathrm{HCl}$ and diluted to $100 \mathrm{~mL}$ with distilled water. A Sep-Pak (Waters Associates, Milford, MA) $\mathrm{C}_{18}$-bonded cartridge ${ }^{1}$ was used to prepare each sample extract for analysis. The cartridge was pre-wetted by passing $5 \mathrm{~mL}$ of methanol through the column followed by $10 \mathrm{~mL}$ of distilled water. The cartridge was loaded with a 2-mL aliquot of the acidified sample extract and washed with $10 \mathrm{~mL}$ of distilled water to remove aqueous contaminants. Phenolics were eluted from the cartridge in $2 \mathrm{~mL}$ methanol and diluted to $6 \mathrm{~mL}$ with a $0.87-M$ acetic acid solution. Phenolic compounds were separated by highperformance liquid chromatography (HPLC) using a BioRad Gradient Module system equipped with a Model 1305 ultraviolet (UV) monitor (Bio-Rad Laboratories, Richmond, CA). Separation of the phenolics was accomplished isocratically using a Bio-Rad $\mathrm{C}_{18}$ ODS-5S reversed-phase column with a water/glacial acetic acid/methanol (67:3:30) solvent phase. The flow rate was $1 \mathrm{~mL} \mathrm{~min}{ }^{-1}$ and UV detection was at $280 \mathrm{~nm}$. Isolated phenolics were quantified against known standards using a Hewlett-Packard Model 3392A integrator (Hewlett-Packard Co., Sunnyvale, CA).

Switchgrass is a strongly determinate plant in which maturation occurs primarily in response to changing photoperiod but can be modified by temperature (Vogel et al., 1985). Therefore, days of the year were used to quantify maturity. Sampling began when the forage was in an early vegetative growth stage and continued until panicle emergence (plants in caged exlosures). Regression analysis (combined strains) was used to quantify relationships between individual forage quality parameters and maturity (days of the year). Since sampling dates were different each year, the linear regression coefficients relating each quality parameter to maturity were used to compare responses across years. Finally, IVDMD values were separately regressed on cell-wall constituent values, using linear and quadratic models to quantify these relationships.

An analysis of variance (ANOVA) using sampling dates as treatments was conducted each year to test for differences among quality parameter means at the different sampling dates. Values used in the ANOVA for each parameter at each sampling date were the means of the three switchgrass strains for each pasture replicate.

An ANOVA was performed on individual quality parameters to compare switchgrass strains within each sample date each year. Quality parameters also were analyzed on an annual basis using a split-plot design in which switchgrass strains served as mainplots and sample dates served as subplots. Similarly, a combined ANOVA, with strains as mainplots and years as subplots, was used to compare responses across the 3-yr study.

\section{RESULTS AND DISCUSSION}

\section{Maturity Effect}

Alkali-labile phenolics detected in the switchgrass forage consisted of (i) protocatechuic acid, (ii) p-hy- 
droxybenzoic acid, (iii) $p$-hydroxybenzaldehyde, (iv) vanillin, (v) $p$-coumaric acid (PCA), and (vi) ferulic acid (FA). However, the first four were detected only in trace amounts relative to PCA and FA and varied little throughout the grazing season. Therefore, only the results for PCA and FA are reported. As expected, forage quality was higher in the grazed forage (Table 1) than in the ungrazed forage (Table 2) throughout each season, presumably due to a relatively higher proportion of leaves in these samples. As the switch- grass matured and leafiness declined, differences in forage composition between the grazed and ungrazed forage were less pronounced. The effect of maturity on all quality parameters was significant $(P<0.01)$ in both forage treatments each year except for FA concentration, which exhibited an inconsistent response (Fig. 1). Increases in PCA were substantial, particularly during 1983 and 1984 , and corresponded to declines in the FA/PCA ratio. The phenolic values at the later stages of maturity are similar to those reported

Table 1. Forage quality constituents and lignin phenolic acids of grazed $\dagger$ switchgrass during three grazing seasons at Mead, NE.

\begin{tabular}{|c|c|c|c|c|c|c|c|c|c|}
\hline \multirow[b]{2}{*}{ Year } & \multirow{2}{*}{$\begin{array}{c}\text { Day } \\
\text { of the } \\
\text { year }\end{array}$} & \multicolumn{8}{|c|}{ Meansł } \\
\hline & & IVDMD & $\mathbf{C P}$ & NDF & ADF & Lignin & FA & PCA & FA/PCA \\
\hline & & & 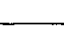 & dry m & - & - & $-\mathrm{g} 1$ & $\mathrm{~F}$ & \\
\hline \multirow[t]{7}{*}{1983} & 160 & 728 & 184 & 620 & 281 & 27 & 3.3 & 2.1 & 1.62 \\
\hline & 171 & 676 & 144 & 680 & 346 & 37 & 3.6 & 3.4 & 1.05 \\
\hline & 181 & 699 & 140 & 647 & 332 & 33 & 3.3 & 3.4 & 0.99 \\
\hline & 195 & 651 & 114 & 667 & 344 & 41 & 3.3 & 3.5 & 0.94 \\
\hline & 203 & 616 & 102 & 666 & 345 & 42 & 3.2 & 4.0 & 0.81 \\
\hline & 210 & 576 & 86 & 696 & 369 & 52 & 3.1 & 5.2 & 0.62 \\
\hline & 216 & 576 & 98 & 687 & 369 & 60 & 3.6 & 5.8 & 0.62 \\
\hline \multirow{11}{*}{$\begin{array}{c}\text { LSD (0.01) } \\
1984\end{array}$} & & 31 & 12 & 34 & 33 & 20 & NS & 1.2 & 0.18 \\
\hline & 152 & 734 & 191 & 666 & 289 & 31 & 4.2 & 2.8 & 1.53 \\
\hline & 159 & 714 & 171 & 703 & 323 & 37 & 3.6 & 3.4 & 1.12 \\
\hline & 169 & 677 & 153 & 693 & 344 & 35 & 3.9 & 4.0 & 0.97 \\
\hline & 177 & 664 & 137 & 708 & 365 & 35 & 3.6 & 4.5 & 0.83 \\
\hline & 183 & 634 & 123 & 719 & 369 & 36 & 3.5 & 4.5 & 0.78 \\
\hline & 190 & 626 & 112 & 742 & 385 & 47 & 4.1 & 6.2 & 0.67 \\
\hline & 197 & 613 & 88 & 778 & 402 & 52 & 3.7 & 6.8 & 0.54 \\
\hline & 204 & 562 & 71 & 770 & 409 & 56 & 3.4 & 6.4 & 0.54 \\
\hline & 211 & 535 & 69 & 772 & 411 & 55 & 3.6 & 6.8 & 0.53 \\
\hline & 218 & 485 & 63 & 778 & 429 & 60 & 3.0 & 6.6 & 0.45 \\
\hline \multirow{9}{*}{$\begin{array}{c}\text { LSD }(0.01 \\
1985\end{array}$} & & 37 & 6 & 35 & 22 & 20 & NS & 1.2 & 0.30 \\
\hline & 151 & 636 & 151 & 698 & 320 & 32 & 6.6 & 6.2 & 1.08 \\
\hline & 157 & 626 & 141 & 692 & 332 & 31 & 7.1 & 6.7 & 1.06 \\
\hline & 164 & 618 & 109 & 694 & 651 & 37 & 6.8 & 7.1 & 0.97 \\
\hline & 170 & 574 & 104 & 726 & 383 & 48 & 4.4 & 7.4 & 0.60 \\
\hline & 178 & 582 & 96 & 734 & 379 & 45 & $\begin{array}{l}4.4 \\
5.6\end{array}$ & 7.7 & 0.73 \\
\hline & 184 & 546 & 81 & 719 & 385 & 45 & 5.1 & 7.9 & 0.65 \\
\hline & 191 & 481 & 69 & 760 & 399 & 53 & 4.4 & 8.3 & 0.54 \\
\hline & 198 & 518 & 77 & 792 & 432 & 57 & 5.0 & 9.1 & 0.56 \\
\hline LSD (0.01) & & 40 & 18 & 32 & 21 & 9 & 0.7 & 1.8 & 0.17 \\
\hline
\end{tabular}

† Forage clipped from the upper one-third of grazed plants.

$\ddagger$ Values represent the mean of three switchgrass strains. IVDMD $=$ in vitro dry matter digestibility, CP $=$ crude protein, NDF $=$ neutral detergent fiber, ADF $=$ acid detergent fiber, FA $=$ ferulic acid, $\mathrm{PCA}=p$-coumaric acid, and FA/PCA $=$ ratio of ferulic acid to $p$-coumaric acid.

Table 2. Forage quality constituents and lignin phenolic acids of ungrazed $†$ switchgrass during two grazing seasons at Mead, NE.

\begin{tabular}{|c|c|c|c|c|c|c|c|c|c|}
\hline \multirow[b]{2}{*}{ Year } & \multirow{2}{*}{$\begin{array}{c}\text { Day of the } \\
\text { year }\end{array}$} & \multicolumn{8}{|c|}{ Means $\ddagger$} \\
\hline & & IVDMD & $\mathrm{CP}$ & NDF & ADF & Lignin & FA & PCA & FA/PCA \\
\hline & & & 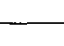 & dry $n$ & - & & $-\mathbf{g}$ & $\mathrm{DF}$ & \\
\hline \multirow[t]{10}{*}{1984} & 152 & 724 & 185 & 696 & 305 & 34 & 4.1 & 3.1 & 1.36 \\
\hline & 159 & 687 & 162 & 704 & 332 & 39 & 4.0 & 3.9 & 1.06 \\
\hline & 169 & 644 & 130 & 723 & 369 & 40 & 3.5 & 4.7 & 0.75 \\
\hline & 177 & 620 & 107 & 752 & 394 & 49 & 3.0 & 5.0 & 0.61 \\
\hline & 183 & 605 & 92 & 756 & 413 & 49 & 3.3 & 5.9 & 0.56 \\
\hline & 190 & 574 & 88 & 771 & 426 & 54 & 3.3 & 6.7 & 0.49 \\
\hline & 197 & 512 & 68 & 793 & 451 & 63 & 3.0 & 7.2 & 0.43 \\
\hline & 204 & 478 & 56 & 777 & 452 & 68 & 2.9 & 6.8 & 0.43 \\
\hline & 211 & 503 & 63 & 776 & 441 & 63 & 3.0 & 6.8 & 0.44 \\
\hline & 218 & 462 & 54 & 769 & 452 & 65 & 2.8 & 6.4 & 0.44 \\
\hline \multirow{9}{*}{$\begin{array}{c}\text { LSD (0.01) } \\
1985\end{array}$} & & 39 & 17 & 43 & 31 & 19 & 0.8 & 1.5 & 0.30 \\
\hline & 151 & 644 & 124 & 725 & 340 & 34 & 6.1 & 6.4 & 0.96 \\
\hline & 157 & 617 & 117 & 728 & 352 & 37 & 5.6 & 6.4 & 0.87 \\
\hline & 164 & 622 & 123 & 667 & 629 & 34 & 6.2 & 6.0 & 1.04 \\
\hline & 170 & 586 & 124 & 693 & 351 & 39 & 6.0 & 6.7 & 0.92 \\
\hline & 178 & 544 & 87 & 734 & 396 & 46 & 6.1 & 8.3 & 0.74 \\
\hline & 184 & 567 & 95 & 702 & 364 & 42 & 6.6 & 8.1 & 0.82 \\
\hline & 191 & 494 & 83 & 749 & 399 & 55 & 6.4 & 8.5 & 0.76 \\
\hline & 198 & 531 & 77 & 757 & 431 & 57 & 6.8 & 8.6 & 0.80 \\
\hline LSD (0.01) & & 25 & 30 & 61 & 40 & 8 & NS & 1.4 & 0.27 \\
\hline
\end{tabular}

Thole plants collected from caged exclosures.

¥ Values represent the mean of three switchgrass strains. IVDMD $=$ in vitro dry matter digestibility, $\mathrm{CP}=\mathrm{crude}$ protein, $\mathrm{NDF}=$ neutral detergent fiber, $\mathrm{ADF}$

$=$ acid detergent fiber, $F A=$ ferulic acid, $P C A=p$-coumaric acid, and FA/PCA $=$ ratio of ferulic acid to $p$-coumaric acid. 

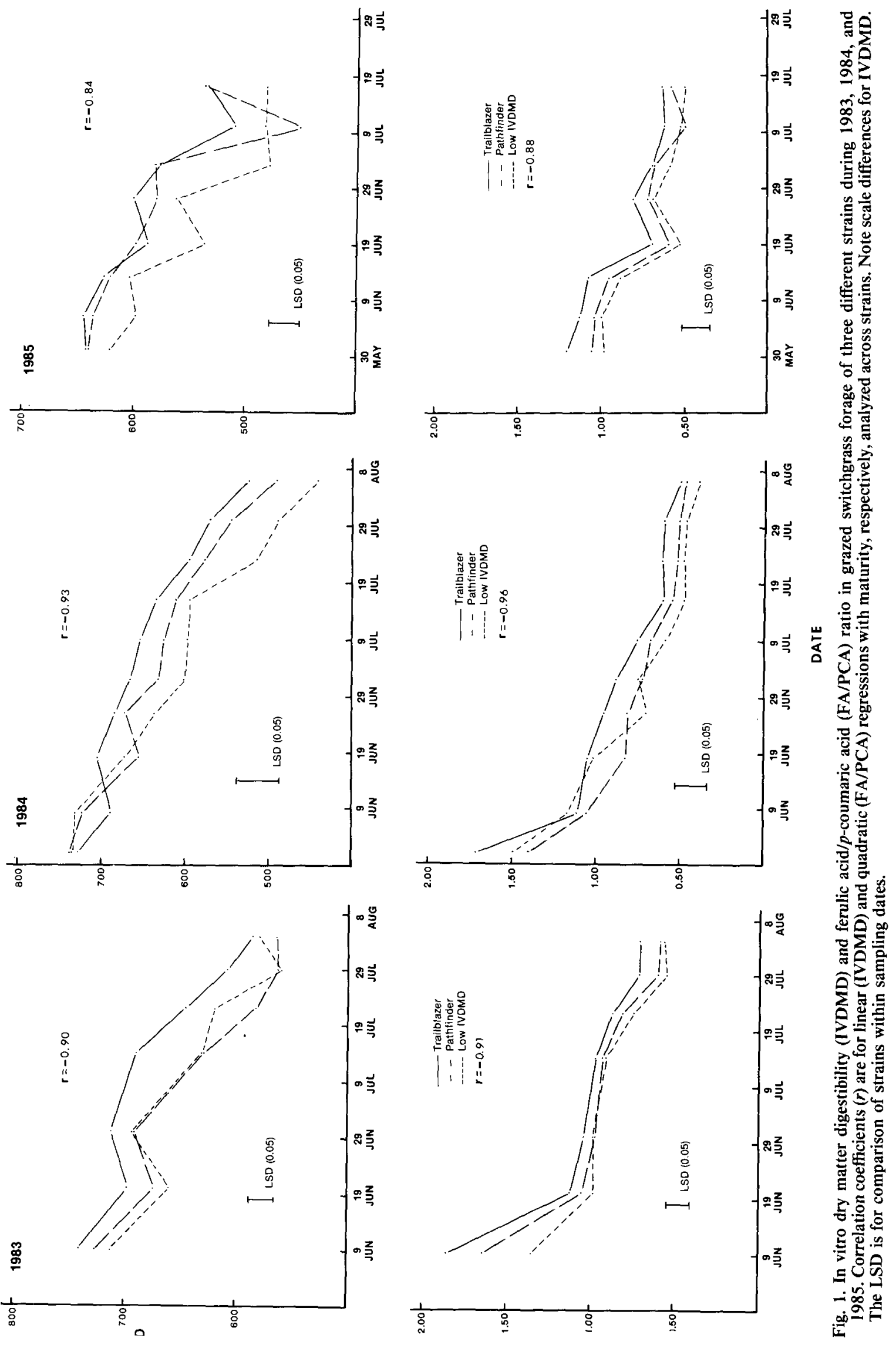
by Cherney et al. (1988) for switchgrass harvested at a late stage of maturity. As expected, NDF, ADF, and lignin concentration increased with maturity, while IVDMD and CP declined.

Regression analysis of each forage-quality parameter with sampling dates indicated significant linear correlations $(r>0.80 ; P<0.001)$ between each trait, except for FA, and maturity within both forage treatments each year (data not shown). Linear regression coefficients representing the daily rate of change for each quality parameter with maturity were used to compare responses between years (Table 3). The response of a few quality parameters indicated some variation across years, particularly within the grazed forage. This was especially evident for FA, which was correlated with maturity in some years and not in others. The slower rate of decline in IVDMD in the ungrazed forage during 1985 (Table 3) appears to reflect the relatively lower initial level of forage digestibility that occurred during the early portion of the grazing season in that year (Table 2).

Researchers (Hartley, 1972; Burritt et al., 1984) examining alkali-labile lignin phenolics in various species of maturing cool-season grasses have reported similar results; however, concentrations of PCA and FA appear to be greater in switchgrass. Burritt et al. (1984), observed that grass samples with high lignin concentration also contained high levels of PCA and low ratios of FA/PCA. In addition, increases in PCA concentration during growth were larger and more consistent than for FA. Accordingly, Akin (1982) found that PCA monomers were markedly more toxic than FA monomers to forage-degrading rumen microflora. Our results with switchgrass appear to support these findings, indicating that PCA is an important cell-wall constituent that may influence forage degradation in grasses.

In 1985, the quality of the switchgrass forage generally was lower than in previous years (Tables 1 and 2 ). This response may have resulted, in part, from the relatively warm temperatures that occurred during growth prior to the grazing period. The average day/ night temperature during April and May was $22 / 10^{\circ} \mathrm{C}$ in 1985 , compared with an average of $18 / 5^{\circ} \mathrm{C}$ for 1983 and 1984. In a study using controlled environments, Akin et al. (1987) reported that alkali-labile phenolic acids in fall fescue (Festuca arundinacea Schreb.) increased under increasing temperature regimens with a concomitant decrease in forage tissue degradation. In the present study, the average PCA and FA concentrations were $>60$ and $55 \%$ higher, respectively, in the grazed forage during $1985 \mathrm{com}-$ pared with the previous $2 \mathrm{yr}$, whereas NDF, ADF, and lignin changed very little. Crude protein and IVDMD values also were lower in 1985. A comparable response was observed in the ungrazed forage.

Linear responses were sufficient to describe relationships between most of the fiber constituents and IVDMD (Table 4). An exception to this was FA, which generally was not well correlated with forage digestibility. In vitro dry matter digestibility and the FA/PCA ratio tended to be quadratically related. This also was apparent for ADF and lignin content, although to a lesser extent. A plot of IVDMD v. FA/ PCA (not shown) indicated that forage digestibility declined more rapidly at higher concentrations of PCA.

The apparent lack of relationship between FA concentration and IVDMD may be due, in part, to the chemical association of FA with other cell-wall components. Scalbert et al. (1985) reported that most of the alkali-labile phenolics extracted from isolated wheat (Triticum aestivum L.) straw lignin consisted of PCA, whereas $\leq 75 \%$ of the FA was ether linked and resistant to alkaline hydrolysis. In work with Italian ryegrass (Lolium multiflorum Lam.), Hartley and Jones (1976) suggested that FA exists, in part, as a dimer (i.e., diferulic acid) that is esterified between cell-wall carbohydrates and core lignin but remains intact when extracted with alkali or released by cel-

Table 3. Linear regression coefficients for individual forage quality constituents with sampling dates in grazed and ungrazed switchgrass forage at Mead, NE.

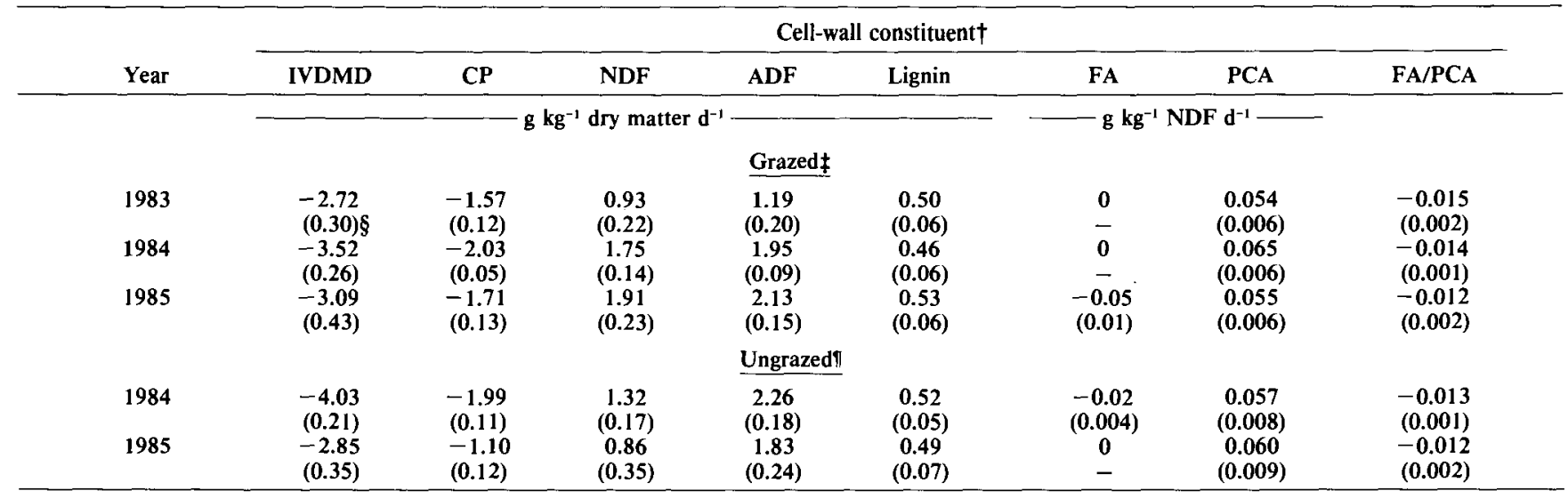

† Regression coefficients were determined using the mean values of three switchgrass strains. Weekly sampling coincided with early vegetative growth stage to panicle emergence each year. IVDMD $=$ in vitro dry matter digestibility, $\mathrm{CP}=$ crude protein, $\mathrm{NDF}=$ neutral detergent fiber, $\mathrm{ADF}=$ acid detergent fiber,

$F A=$ ferulic acid, PCA $=p$-coumaric acid and FA/PCA $=$ ratio of ferulic acid to $p$-coumaric acid.

$¥$ Forage clipped from the upper one-third of grazed plants.

$\S$ Values in parentheses are the standard errors $( \pm)$ of the regression coefficients.

I Whole plants collected from caged exclosures. 
lulase digestion. These observations, and the inconsistent relationship between FA concentration and maturity observed in the present study, suggest that extraction methods based on alkaline hydrolysis may not accurately assess the role of FA in fiber degradation processes. However, our results indicate that PCA

Table 4. Coefficients of determination $\dagger$ for cell-wall constituents with in vitro dry matter digestibility in grazed and ungrazed switchgrass during three grazing seasons at Mead, NE.

\begin{tabular}{|c|c|c|c|c|c|c|}
\hline \multirow{2}{*}{$\begin{array}{l}\text { Cell-wall } \\
\text { constituent }\end{array}$} & \multicolumn{2}{|c|}{1983} & \multicolumn{2}{|c|}{1984} & \multicolumn{2}{|c|}{1985} \\
\hline & Linear & Quadratic & Linear & Quadratic & Linear & Quadratic \\
\hline \multicolumn{7}{|c|}{ Grazed§ } \\
\hline NDF $\ddagger$ & $0.64^{* *}$ & NS & $0.67^{* *}$ & NS & $0.58 * *$ & NS \\
\hline$A D F$ & $0.67^{* *}$ & $0.74^{*}$ & $0.83^{* *}$ & $0.90^{* *}$ & $0.69 * *$ & NS \\
\hline Lignin & $0.74^{* *}$ & NS & $0.70^{* *}$ & NS & $0.69^{* *}$ & NS \\
\hline FA & NS & NS & $0.35^{* *}$ & NS & $0.64^{* *}$ & NS \\
\hline PCA & $0.81^{* *}$ & NS & $0.67^{* *}$ & NS & $0.72^{* *}$ & NS \\
\hline FA/PCA & $0.76^{* *}$ & $0.88^{* *}$ & $0.74^{* *}$ & $0.88^{* *}$ & $0.76^{* *}$ & $0.83^{* *}$ \\
\hline$n$ & 21 & 21 & 30 & 30 & 24 & 24 \\
\hline \multicolumn{7}{|c|}{ Ungrazed $\pi$} \\
\hline NDF & & & $0.69^{* *}$ & NS & $0.30^{* *}$ & NS \\
\hline ADF & & & $0.86^{* *}$ & NS & $0.66^{* *}$ & NS \\
\hline Lignin & & & $0.86^{* *}$ & NS & $0.66^{* *}$ & $0.86^{* *}$ \\
\hline $\mathbf{F A}$ & & & $0.37^{* *}$ & NS & NS & NS \\
\hline PCA & & & $0.71^{* *}$ & NS & $0.69^{* *}$ & NS \\
\hline FA/PCA & & & $0.74^{* *}$ & $0.85^{\text {** }}$ & $0.55^{* *}$ & NS \\
\hline 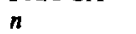 & & & 30 & 30 & 24 & 24 \\
\hline
\end{tabular}

**, *** Significant at the 0.05 and 0.01 probability levels, respectively.

$\dagger$ Correlations were determined using the mean values of three switchgrass strains.

$¥ \mathrm{NDF}=$ neutral detergent fiber, $\mathrm{ADF}=$ acid detergent fiber, $\mathrm{FA}=$ ferulic acid, $\mathrm{PCA}=\boldsymbol{p}$-coumaric acid, FA/PCA $=$ ratio of ferulic acid to $p$-coumaric acid, and $n=$ sample size.

$\S$ Forage clipped from the upper one-third of grazed plants.

$\pi$ Whole plants collected from caged exclosures. concentration increases substantially in switchgrass cell walls with maturity and may negatively influence forage digestibility.

\section{Genetic Effects}

Performance of cattle grazing these pastures and the IVDMD of the strains over the grazing season for 1983 and 1985 have been previously reported (Anderson et al., 1988). The objective of this portion of the study was to determine if the previously reported genetic differences among the switchgrass strains for IVDMD is associated with genetic difference in FA and PCA concentration of the forages. The three strains in this study were all developed from the same germplasm source and consistently flower on the same date in eastern Nebraska (Vogel et al., 1981; Vogel et al, 1984). Hence, the three strains are similar in phenological development throughout the growing season, so any differences among strains for quality traits on a sample are not due to maturity differences.

In vitro dry matter digestibility was consistently higher in Trailblazer than in Pathfinder and the lowIVDMD strain as previously reported by Anderson et. al. (1988), (Tables 5 and 6). Lower PCA concentrations and high FA/PCA ratios were associated with high forage digestibility. This was particularly evident in both forage sampling treatments when these parameters were considered across all grazing seasons; however, differences in PCA concentration were less apparent when switchgrass strains were compared within grazing seasons. Some variation in FA concentration also occurred; however, responses among

Table 5. Forage quality constituents in three grazed $\dagger$ switchgrass strains during three grazing seasons at Mead, NE.

\begin{tabular}{|c|c|c|c|c|c|c|c|c|}
\hline \multirow[b]{2}{*}{ Strain } & \multicolumn{8}{|c|}{ Cell-wall constituents $\ddagger$} \\
\hline & IVDMD & $\mathbf{C P}$ & NDF & ADF & Lignin & FA & PCA & FA/PCA \\
\hline & \multicolumn{7}{|c|}{$\longrightarrow \mathrm{g} \mathrm{kg}^{-1}$ dry matter $\longrightarrow$} & \\
\hline \multicolumn{9}{|c|}{$\underline{1983}$} \\
\hline Trailblazer & 669 & 127 & 662 & 338 & 41 & 3.5 & 3.7 & 1.04 \\
\hline Pathfinder & 633 & 119 & 672 & 347 & 43 & 3.4 & 4.0 & 0.94 \\
\hline Low-IVDMD & 636 & 125 & 664 & 338 & 40 & 3.2 & 4.0 & 0.87 \\
\hline LSD & 17 & 6 & - & - & - & 0.3 & - & 0.14 \\
\hline Signif. level§ & 0.01 & 0.06 & NS & NS & NS & 0.01 & NS & 0.02 \\
\hline \multicolumn{9}{|c|}{1984} \\
\hline Trailblazer & 649 & 117 & 727 & 368 & 40 & 3.8 & 4.9 & 0.88 \\
\hline Pathfinder & 627 & 119 & 738 & 371 & 44 & 3.4 & 5.0 & 0.76 \\
\hline Low-IVDMD & 602 & 116 & 734 & 378 & 49 & 3.8 & 5.6 & 0.75 \\
\hline LSD & - & 2 & - & - & 6 & - & - & - \\
\hline Signif. level§ & NS & 0.10 & NS & NS & 0.10 & NS & NS & NS \\
\hline \multicolumn{9}{|c|}{1985} \\
\hline Trailblazer & 591 & 105 & 728 & 370 & 42 & 6.0 & 7.2 & 0.85 \\
\hline Pathfinder & 581 & 106 & 725 & 370 & 43 & 5.5 & 7.5 & 0.76 \\
\hline Low-IVDMD & 546 & 99 & 727 & 377 & 46 & 5.4 & 7.8 & 0.71 \\
\hline LSD & 33 & - & - & - & 3 & - & - & 0.11 \\
\hline Signif. level§ & 0.07 & NS & NS & NS & 0.05 & NS & NS & 0.08 \\
\hline \multicolumn{9}{|c|}{ 1983-1985 } \\
\hline Trailblazer & 635 & 117 & 706 & 359 & 41 & 4.4 & 5.3 & 0.92 \\
\hline Pathfinder & 614 & 115 & 712 & 362 & 43 & 4.1 & 5.5 & 0.82 \\
\hline Low-IVDMD & 595 & 113 & 708 & 364 & 45 & 4.1 & 5.8 & 0.78 \\
\hline LSD & 29 & 2 & 3 & - & - & 0.3 & 0.4 & 0.10 \\
\hline Signif. level§ & 0.06 & 0.05 & 0.10 & NS & NS & 0.04 & 0.09 & 0.01 \\
\hline
\end{tabular}

+ Forage clipped from the upper one-third of grazed plants.

‡ IVDMD $=$ in vitro dry matter digestibility, $C P=$ crude protein, NDF = neutral detergent fiber, $A D F=$ acid detergent fiber, $F A=$ ferulic acid, $P C A=p$ coumaric acid, and FA/PCA = ratio of ferulic acid to $p$-coumaric acid.

$\S$ Significance level of the $F$ test for treatment means. 
switchgrass strains were inconsistent between grazed and ungrazed forages.

During 1984 and 1985, the average lignin concentration in the grazed forage was significantly $(P \leq$ $0.10)$ lower in Trailblazer than in the low-IVDMD strain. A similar response was not apparent in the ungrazed forage or when lignin concentration was considered across all grazing seasons. In grazed forage, $\mathrm{CP}$ content was highest in Trailblazer when averaged across all grazing seasons. However, CP differences between strains in 1983 and 1984 were inconsistent with differences in IVDMD, and no differences in CP content were observed in the ungrazed forages. Strain differences in detergent-fiber constituents were not apparent or were unrelated to differences in IVDMD.

Previous studies with these same switchgrass strains documented comparable responses in both hay (Vogel et al., 1984) and grazed forage (Anderson et al., 1988) when using the detergent system of analysis. Vogel et al. (1984) observed small differences in NDF between these strains, suggesting that improvement in the IVDMD of Trailblazer switchgrass was due, in part to a decrease in cell-wall concentration. The results reported by Anderson et al. (1988) and those observed in this study (Tables 1 and 2) indicate that detergentfiber components do not account for the observed differences in IVDMD. Ehlke et al. (1986) reached a similar conclusion following evaluation of NDF and ADF concentrations in divergent populations of smooth bromegrass genotypes selected for increased IVDMD; however, lignin concentration was a major limiting factor to IVDMD. Evidence for a similar effect of lignin concentration on IVDMD among the switchgrass strains in our study was indicated only in the grazed forage (Table 5).

Researchers evaluating alkali-labile phenolics in other forage grasses (Hartley, 1972; Chaves et al., 1982; Burritt et al., 1984) have reported that high lev- els of PCA and low FA/PCA ratios are associated with low forage digestibility. The responses observed in our study seem to support these findings, although strain differences for these quality parameters were not always detected (Tables 5 and 6). Ferulic acid concentration did not appear to be related to strain differences in IVDMD, suggesting a less important role of this cell-wall constituent in fiber digestion processes. In in vitro digestion studies investigating the effect of phenolic monomers on orchardgrass (Dactylis glomerata L.), Akin (1982) found that FA was markedly less toxic than PCA to forage-degrading rumen microflora. Other studies (Azuma et al., 1985; Scalbert et al., 1985) suggest that FA resides in a different structural environment than PCA within the cell wall, indicating a differential susceptibility of these compounds to alkaline hydrolysis.

In general, decreases in strain IVDMD followed a linear trend throughout each grazing season, whereas FA/PCA ratios exhibited a curvilinear response, declining more rapidly early in the season (Figures 1,2 , and 3). A significant $(P<0.05)$ strain $\times$ date interaction for IVDMD occurred among the grazed forages during 1983 and 1985; however, this appeared to be attributable to measured responses at only one or two sampling dates. Strain $\times$ date interactions were not detected for the FA/PCA ratio. Except for a few dates, the strains ranked similarly (Trailblazer $>$ Pathfinder $>$ low-IVDMD) for IVDMD and the FA/PCA ratio during the grazing season for each of the $3 \mathrm{yr}$ of this study.

During grass growth, increases in both PCA and lignin concentration occur which may result in increased esterified cross-linkages between lignin and cell-wall carbohydrates (Hartley, 1972; Mueller-Harvey et al., 1986). Recent studies (Sawai et al., 1983; Jung and Sahlu, 1986) have demonstrated that cellulose degradation is significantly depressed by esterified cinnamic

Table 6. Forage quality constituents in three ungrazed $\dagger$ switchgrass strains during two grazing seasons at Mead, NE.

\begin{tabular}{|c|c|c|c|c|c|c|c|c|}
\hline \multirow[b]{2}{*}{ Strain } & \multicolumn{8}{|c|}{ Cell-wall constituentsł } \\
\hline & IVDMD & $\mathbf{C P}$ & NDF & $\mathrm{ADF}$ & Lignin & FA & PCA & FA/PCA \\
\hline & \multicolumn{5}{|c|}{$\mathrm{g} \mathrm{kg}^{-1}$ dry matter } & \multicolumn{3}{|c|}{$\longrightarrow \mathrm{g} \mathrm{kg}^{-1} \mathrm{NDF}$} \\
\hline \multicolumn{9}{|c|}{$\underline{1984}$} \\
\hline Trailblazer & 594 & 100 & 746 & 398 & 52 & 3.3 & 5.3 & 0.71 \\
\hline Pathfinder & 582 & 101 & 759 & 410 & 52 & 2.9 & 5.2 & 0.61 \\
\hline Low-IVDMD & 567 & 101 & 750 & 402 & 53 & 3.7 & 6.3 & 0.66 \\
\hline LSD & 20 & - & 9 & 8 & - & 0.6 & 0.9 & - \\
\hline Signif. level§ & 0.05 & NS & 0.01 & 0.10 & NS & 0.06 & 0.08 & NS \\
\hline \multicolumn{9}{|c|}{$\underline{1985}$} \\
\hline Trailblazer & 588 & I06 & 722 & 372 & 40 & 6.4 & 7.1 & 0.92 \\
\hline Pathfinder & 577 & 104 & 718 & 367 & 44 & 6.2 & 7.1 & 0.90 \\
\hline Low-IVDMD & 561 & 101 & 717 & 372 & 44 & 6.0 & 7.8 & 0.77 \\
\hline LSD & 19 & - & - & - & - & - & - & 0.12 \\
\hline Signif. level§ & 0.10 & NS & NS & NS & NS & NS & NS & 0.01 \\
\hline \multicolumn{9}{|c|}{ 1984-1985 } \\
\hline Trailblazer & 591 & 103 & 734 & 385 & 46 & 4.9 & 6.2 & 0.82 \\
\hline Pathfinder & 580 & 102 & 739 & 388 & 48 & 4.5 & 6.2 & 0.75 \\
\hline Low-IVDMD & 564 & 101 & 734 & 387 & 49 & 4.9 & 7.1 & 0.71 \\
\hline LSD & 11 & - & - & - & - & 0.2 & 0.6 & 0.06 \\
\hline Signif, level§ & 0.01 & NS & NS & NS & NS & 0.05 & 0.07 & 0.10 \\
\hline
\end{tabular}

† Whole plants collected from caged exclosures.

$¥$ IVDMD $=$ in vitro dry matter digestibility, $\mathrm{CP}=$ crude protein, $\mathrm{NDF}=$ neutral detergent fiber, $\mathrm{ADF}=$ acid detergent fiber, $\mathrm{FA}=$ ferulic acid, $\mathrm{PCA}=\boldsymbol{p}$ coumaric acid, and $\mathrm{FA} / \mathrm{PCA}=$ ratio of ferulic acid to $p$-coumaric acid.

$\S$ Significance level of the $F$ test for treatment means. 
acids. This response is probably due to a physical inhibition that restricts cellulase accessibility into the cell-wall matrix. In addition, free cinnamic acids such as PCA, which are released from the cell wall during digestion, may subsequently exert toxic effects on forage-degrading microorganisms (Akin, 1982; Akin and Rigsby, 1985; Varel and Jung, 1986).

Trailblazer and the low-IVDMD strain were divergently selected from the same population for differences in IVDMD. The results reported here indicate that correlated responses for PCA content and the FA/ PCA ratio occurred as a result of this selection, indicating that these traits are heritable in switchgrass and that they are genetically correlated to IVDMD. A possible explanation for this correlated response is that the variation in PCA may have been responsible, in part, for the observed differences in IVDMD among the switchgrass strains.

\section{REFERENCES}

Akin, D.E. 1982. Forage cell wall degradation and p-coumaric, ferulic, and sinapic acids. Agron. J. 74:424-428.

Akin, D.E., S.L. Fales, L.L. Rigsby, and M.E. Snook. 1987. Temperature effects on leaf anatomy, phenolic acids, and tissue digestibility in tall fescue. Agron. J. 79:271-275.

Akin, D.E., and L.L. Rigsby. 1985. Influence of phenolic acids on rumen fungi. Agron. J. 77:180-182.

Anderson, B.E., J.K. Ward, K.P. Vogel, M.G. Ward, H.J. Gorz, and F.A. Haskins. 1988. Forage quality and performance of yearlings grazing switchgrass strains selected for differing digestibility. J. Anim. Sci. 66:2239-2244.

Association of Official Analytical Chemists. 1975. Methods of analysis. AOAC, Washington, DC.

Azuma, J., T. Nomura, and T. Koshijima. 1985. Lignin-carbohydrate complexes containing phenolic acids isolated from the culms of bamboo. Agric. Biol. Chem. 49:2661-2669.

Burritt, E.A., A.S. Bittner, J.C. Street, and M.J. Anderson. 1984. Correlations of phenolic acids and xylose content of cell wall with in vitro dry matter digestibility of three maturing grasses. J. Dairy Sci. 67:1209-1213.

Chaves, C.M., J.E. Moore, H.A. Moye, and W.R. Ocumpaugh. 1982. Separation, identification, and quantification of lignin saponification products extracted from digitgrass and their relation to forage quality. J. Anim. Sci. 54:196-203.

Cherney, J.H., K.D. Johnson, J.J. Volenec, and K.S. Anliker. 1988. Chemical composition of herbaceous grass and legume species grown for maximum biomass production. Biomass 17:215-238.

Cowling, E.B. 1975. Physical and chemical constraints in the hydrolysis of cellulose and lignocellulosic materials. Biotechnol. Bioeng. Symp 5:163-181.

Duble, R.L., J.A. Lancaster, and E.C. Holt. 1971. Forage characteristics limiting animal performance on warm-season perennial grasses. Agron. J. 63:795-798.

Ehlke, N.J., M.D. Casler, P.N. Drolsom, and J.S. Shenk. 1986. Divergent selection for in vitro dry matter digestibility in smooth bromegrass. Crop Sci. 26:1123-1126.
Gaillard, B.D.E., and G.N. Richards. 1975. Presence of soluble lignin-carbohydrate complexes in the bovine rumen. Carbohydrate Res. 42:135-145.

Goering, H.K., and P.J. Van Soest. 1970. Forage fiber analyses (apparatus, reagents, procedures, and some applications). USDA-ARS Agric. Handb. 379. U.S. Gov. Printing Office, Washington, DC.

Gordon, A.J. 1975. A comparison of some chemical and physical properties of alkali lignins from grass and lucerne hays before and after digestion by sheep. J. Sci. Food Agric. 26:1551-1559.

Harking, J.M. 1973. Lignin. p. 323-373. In G.W. Butler and R.W. Bailey (ed.) The chemistry and biochemistry of herbage, Vol. I. Academic Press, New York.

Hartley, R.D. 1972. p-Coumaric and ferulic acid components of cell walls of ryegrass and their relationships with lignin and digestibility. J. Sci. Food Agric. 23:1347-1354.

Hartley, R.D., and E.C. Jones. 1976. Diferulic acid as a component of cell walls of Lolium multiflorum. Phytochemistry 15:1157-1160.

Hartley, R.D., and E.C. Jones. 1977. Phenolic components and degradability of cell walls of grass and legume species. Phytochemistry 16:1531-1534.

Jung, H.G. and T. Sahlu. 1986. Depression of cellulose digestion by esterified cinnamic acids. J. Sci. Food Agric. 37:659-665.

Jung, H.G., and K.P. Vogel. 1986. Influence of lignin on digestibility of forage cell wall material. J. Anim. Sci. 62:1703-1712.

Moore, J.E., and G.O. Mott. 1973. Structural inhibitors of quality in tropical grasses. p. 53-98. In A.G. Matches (ed.) Anti-quality components of forages. CSSA Spec. Publ. 4. CSSA, Madison, WI.

Morrison, I.M. 1974. Structural investigations on the lignin-carbohydrate complexes of Lolium perenne. Biochem. J. 139:197-204.

Mueller-Harvey, I., R.D. Hartley, P.J. Harris, and E.H. Curzon. 1986. Linkage of $p$-coumaroyl and feruloyl groups to cell wall polysaccharides of barley straw. Carbohydrate Res. 148:71-85.

Sawai, A.T. Kondo, and S. Ara. 1983. Inhibitory effects of phenolic acid esters on degradability of forage fibers. J. Jpn. Grassl. Sci. 29:175-179.

Scalbert, A., B. Monties, J.Y. Lallemand, E. Guittet, and C. Rolando. 1985. Ether linkage between phenolic acids and lignin fractions from wheat straw. Phytochemistry 24:1359-1362.

Tilley, J.M.A., and R.A. Terry. 1963. A two stage technique for in vitro digestion of forage crops. J. Br. Grassland Soc. 18:104-111.

Van Soest, P.J. 1973. The uniformity and nutritive availability of cellulose. Fed. Proc. 32:1804-1808.

Van Soest, P.J., and J.B. Robertson. 1980. Systems of analysis for evaluating fibrous feeds. p. 49-60. In W.J. Pigden et al. (ed.) Standardization of analytical methodology for feeds. Int. Development Res. Ctr., Ottawa, Canada.

Varel, V.H., and H.G. Jung. 1986. Influence of forage phenolics on ruminal fibrolytic bacteria and in vitro fiber digestion. Appl. Environ. Microbiol. 52:275-280.

Vogel, K.P., R. Britton, H.J. Gorz, and F.A. Haskins. 1984. In vitro and in vivo analyses of hays of switchgrass strains selected for high and low in vitro dry matter digestibility. Crop Sci. 24:977-980.

Vogel, K.P., C.L. Dewald, H.J. Gorz, and F.A. Haskins. 1985. Improvement of switchgrass, indiangrass, and eastern gamagrass: current status and future. p. 51-62. In Range plant improvement in western North America. Proc. Soc. Range Management annual meetings, Salt Lake City, UT. 11-14 Feb. 1985. Soc. Range Management, Denver, CO.

Vogel, K.P., F.A. Haskins, and H.J. Gorz. 1981. Divergent selection for in vitro dry matter digestibility in switchgrass. Crop Sci. 21:39-41.

Ward, M.G., J.K. Ward, B.E. Anderson, and K.P. Vogel. 1989. Selectivity and in vivo digestibility of switchgrass strains selected for differing digestibility. J. Animal Sci. 67:1418-1424. 